Corrigendum

\title{
Corrigendum to "miR-375 Inhibits the Proliferation and Invasion of Nasopharyngeal Carcinoma Cells by Suppressing PDK1"
}

\author{
Xu Jia-yuan, Song Wei, Lu Fang-fang, Dai Zhi-jian, Cao Long-he, and Lin Sen \\ Department of Otolaryngology, The Third Affiliated Hospital of Wenzhou Medical University, Ruian, Zhejiang, China \\ Correspondence should be addressed to Lin Sen; lnns@163.com
}

Received 19 October 2020; Accepted 19 October 2020; Published 31 October 2020

Copyright ( $2020 \mathrm{Xu}$ Jia-yuan et al. This is an open access article distributed under the Creative Commons Attribution License, which permits unrestricted use, distribution, and reproduction in any medium, provided the original work is properly cited.

In the article titled "miR-375 Inhibits the Proliferation and Invasion of Nasopharyngeal Carcinoma Cells by Suppressing PDK1" [1], the $Y$-axes labelling of Figures 1(a) and 1(b) were inverted by mistake. The corrected figure is shown below and is listed as Figure 1. 


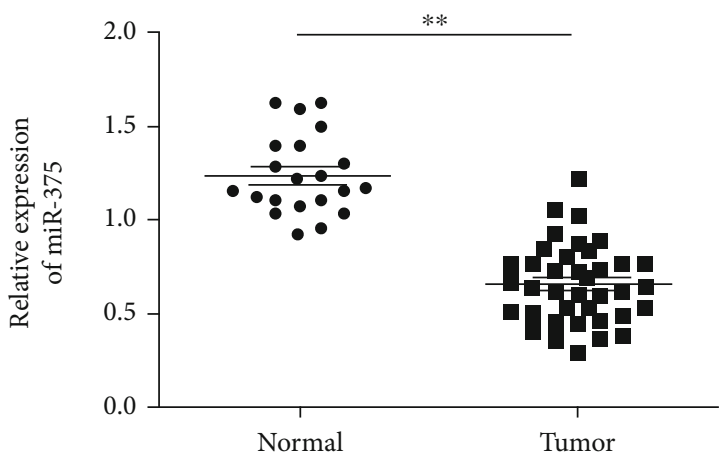

(a)

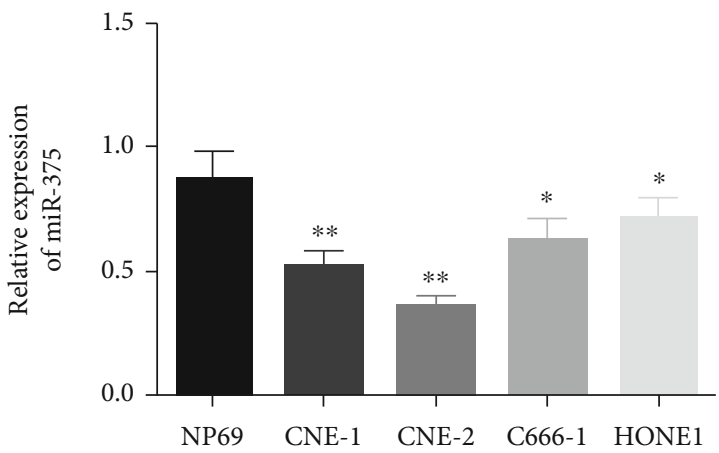

(c)

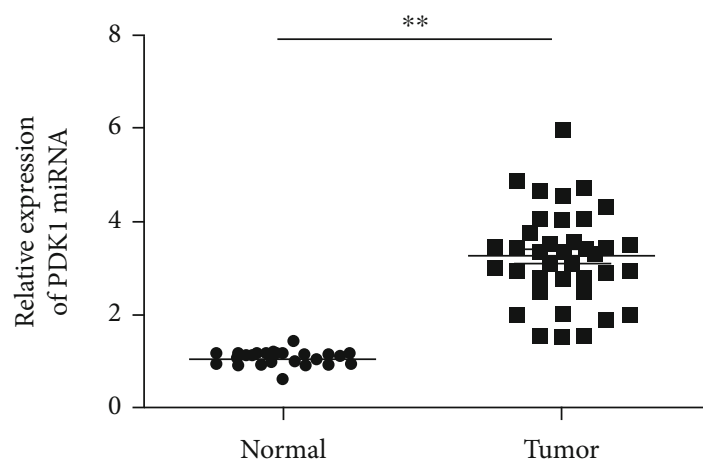

(b)

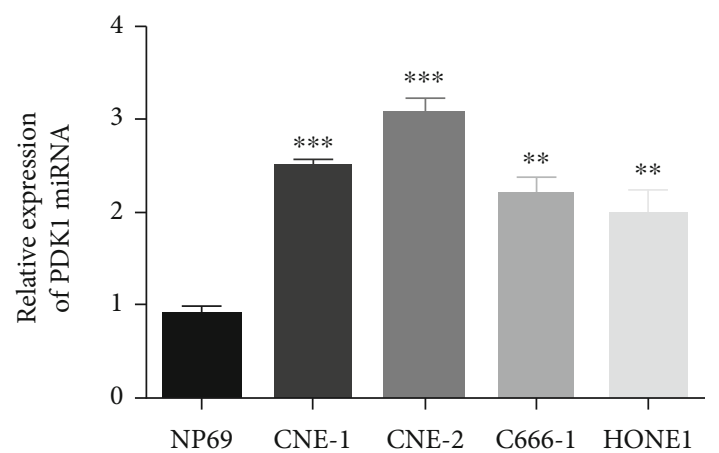

(d)

Figure 1: Expression levels of miR-375 and PDK1 in NPC tissues and cell lines were assessed. (a, b) qRT-PCR was performed to measure expression levels of miRNAs and PDK1 in 23 normal samples and in 38 NPC samples. miR-375 is downregulated in NPC tissue, compared with normal tissue, while PDK1 is upregulated in NPC tissue, compared with normal tissue (Student's $t$-test, ${ }^{* *} P<0.01$ ). (c, d) qRT-PCR was performed to evaluate miR-375 expression in the N69 epithelial normal nasopharynx cell line and NPC cell lines (CNE1,CNE-2, C666-1, and HONE1). Conversely, levels of PDK1 were markedly increased in NPC cell lines, compared to NP69 (CNE-1, CNE2, C666-1, and HONE1) (Student's $t$-test, ${ }^{*} P<0.05,{ }^{* *} P<0.01$, and ${ }^{* * *} P<0.001$ ). Cell lines CNE-2 and CNE-1 showed the greatest difference in miR-375 expression levels when compared to NP69 cells and were used for subsequent analyses. Each assay was conducted in duplicate, three times. Values are presented \pm s.e.m.

\section{References}

[1] X. Jia-yuan, S. Wei, L. Fang-fang, D. Zhi-jian, C. Long-he, and L. Sen, "miR-375 inhibits the proliferation and invasion of nasopharyngeal carcinoma cells by suppressing PDK1," BioMed Research International, vol. 2020, Article ID 9704245, 2020. 